Brazilian Journal
of Chemical
Engineering

\title{
ALTERNATIVE FUELS COMPOSED BY BLENDS OF NONIONIC SURFACTANT WITH DIESEL AND WATER: ENGINE PERFORMANCE AND EMISSIONS
}

\author{
A. A. Dantas Neto*, M. R. Fernandes, E. L. Barros Neto, \\ T. N. Castro Dantas and M. C. P. A. Moura \\ Universidade Federal do Rio Grande do Norte, UFRN, \\ Campus Universitário, Centro de Tecnologia, CT - DEQ - PPGEQ, \\ Phone: + (55) (84) 3215-3773, Fax: + (55) (84) 3215-3770, \\ Postal Code: 59072-970, Natal - RN, Brazil. \\ E-mail: aadantas@eq.ufrn.br
}

(Submitted: July 12, 2010 ; Revised: March 29, 2011 ; Accepted: April 5, 2011)

\begin{abstract}
Diesel-based microemulsions and a surfactant/diesel blend, using ethoxylated (5 EO) nonylphenol as surfactant, were prepared and tested in a diesel engine to evaluate its performance and emissions. The following properties were evaluated: density, viscosity, cloud point and corrosiveness. Experimental results showed that density and viscosity were greater than those obtained for neat diesel. Cloud point and corrosiveness were not affected by water and surfactant. Specific fuel consumption of the microemulsion systems was greater than that of diesel, but the small droplets of water improved diesel combustion. Compared with diesel, an increase in carbon monoxide (CO) and nitrogen oxide (NOx) emissions and a decrease in black smoke emissions were obtained. In general, only microemulsions with up to $6 \%$ water are in accord with Brazilian diesel/biodiesel fuel regulations and specifications.

Keywords: Diesel; Diesel engine; Surfactant; Microemulsion; Emissions.
\end{abstract}

\section{INTRODUCTION}

Diesel oil is a fossil fuel used in compression ignition engines. Combustion of diesel fuel contributes greatly to environmental pollution due to carbon monoxide, nitrogen oxides and particulate matter emissions to the atmosphere. The necessity of reducing gas emissions and the search for better engine performance have increased the interest in alternative fuels or emulsion/microemulson systems, such as: blends of diesel with biodiesel and vegetable oils, diesel-based microemulsions, natural gas/diesel blends, and water-in-oil emulsions (Crookes et al., 1997; Nabi et al., 2006; Rakopoulos et al., 2006; Sarvi et al., 2009; Ochoterena et al., 2010;
Papagiannakis et al., 2010; Lif et al., 2010; Singh et al., 2010).

Microemulsions are mixtures of two immiscible liquids, like water and oil, which are stabilized by a surfactant, located at the oil/water interface, and sometimes a co-surfactant when an ionic surfactant is used (Hoar and Schulman, 1943). They are formed spontaneously and exhibit nano-dispersed structures. Microemulsions have special features, such as: high thermodynamic stability, large interfacial area, ultralow interfacial tension and optical transparency.

The liquid usually in excess in a microemulsion system is termed the continuous or external phase, while the liquid dispersed in small droplets is termed the internal or dispersed phase. When the external

*To whom correspondence should be addressed 
phase consists of water and the organic phase is the internal phase, the system is called "oil-in-water" $(\mathrm{o} / \mathrm{w})$. If the water is finely dispersed in the organic phase the system is named "water-in-oil" (w/o). Bicontinuous systems can also be formed when both components form continuous interpenetrating domains, with none of the two circling each other.

It is well known that the addition of water to diesel, forming $\mathrm{o} / \mathrm{w}$ microemulsions and/or emulsion systems, leads to reduction in NOx, carbon monoxide (CO), total unburned hydrocarbon (HC) and particulate matter emissions. This is attributed to improved combustion efficiency and reduction in exhaust gas temperatures, which are important factors in reducing pollutant emissions (Peckham, 2001; Wang and Fu, 2001; Abu-Zaid, 2004; Park and Kwak, 2004; Armas et al., 2005; Lif and Holmberg, 2006; Bemert et al., 2009; Alahmer et al., 2010).

Lif and Holmberg (2006) evaluated the influence of water on emissions and on combustion efficiency of diesel-based microemulsions, diesel-based twophase and three-phase emulsions and water-invegetable oil emulsions. The importance of using these fuels is mainly attributed to environmental conservation, due to a reduction in gaseous emissions, incorporation of water to fossil fuels and the use of renewable raw materials.

Castro Dantas et al. (2001) developed dieselbased microemulsions using blends of diesel with vegetable oils (soy, palm and castor oils). Pseudoternary phase diagrams were constructed to evaluate the main factors that influenced the obtaining of microemulsion systems, such as: co-surfactant/surfactant ratio and nature of surfactant, co-surfactant and oil phase. The best microemulsions were obtained with blends of diesel and soybean oil, indicating the possibility of using these blends as alternative fuels.

Fernandes et al. (2006) submitted a request for a patent concerning the development of diesel-based microemulsion systems composed of an ionic surfactant (1 to $5 \mathrm{wt.} \%$ ), water (1 to $9 \mathrm{wt} . \%$ ) and diesel fuel (at least 86 wt.\%). These w/o microemusion fuels presented good thermal stability and their physical-chemical properties were in accord with the regulatory criteria for diesel oil in Brazil (ANP, 2006). They concluded that the new microemulsion systems can be used in diesel engines with good performance and low gaseous emissions.

Lin and Wang (2004) produced two-phase emulsions (w/o) and three-phase emulsions (o/w/o) to feed a diesel engine. They investigated the engine performance and emissions of these systems with various water contents and compared them to regular diesel oil. It was observed that a greater water content generated lower calorific values. They observed that emulsions had lower exhaust gas temperature, $\mathrm{CO}_{2}, \mathrm{CO}, \mathrm{NOx}$, and $\mathrm{O}_{2}$ emissions and smoke opacity. The three-phase emulsions produced higher exhaust gas temperatures and lower $\mathrm{CO}$ and NOx emissions as compared with two-phase emulsions with the same water proportion.

Selim and Elfeky (2001) carried out experiments in a single cylinder pre-combustion chamber diesel engine (Helman 111) using different water/diesel emulsion ratios. The effect of water/diesel emulsions on heat flux, combustion chamber metal temperature and thermal loading showed that diesel engines running with water/diesel emulsions should be more reliable than those running with pure diesel due to the drop in temperature in the combustion chamber, resulting in an increased life of metal parts and the requirement of a less complex cooling system.

In this work w/o diesel-based microemulsions were developed to be used in a stationary diesel engine. The main target of this research was the addition of the non-ionic surfactant ethoxylated nonylphenol with five oxy-ethylene units (ethoxylate chain length) to obtain the microemulsions. The use of this surfactant is not reported in the literature for diesel-based microemulsions. The percentage of surfactant in the mixture was fixed at 15 wt.\% to evaluate the maximum amount of water that could be added to the system considering that it should remain as a microemulsion. A blend of diesel with surfactant was also tested to obtain the surfactant influence. Fuel consumption and carbon monoxide, nitrogen oxides, unburned hydrocarbons, and black smoke emissions were evaluated. The results were compared with neat diesel.

\section{MATERIALS AND METHODS}

\section{Materials}

Surfactant, ethoxylated nonylphenol 5 EO (NFE 5), was kindly supplied by Oxiteno (Brazil). Diesel used in the experimental procedure (without additives; distillation curve: IBP - Initial Boiling Point $-129^{\circ} \mathrm{C}-5 \%, 162^{\circ} \mathrm{C}-10 \%, 180^{\circ} \mathrm{C}-30 \%$, $250^{\circ} \mathrm{C}-50 \%, 289^{\circ} \mathrm{C}-70 \%, 330^{\circ} \mathrm{C}-85 \%, 368^{\circ} \mathrm{C}-$ $90 \%$; $383^{\circ} \mathrm{C}$; IAT- total acid number -0.33 ; flash point $-40.3^{\circ} \mathrm{C}$; density at $20^{\circ} \mathrm{C}-0.820 \mathrm{~g} / \mathrm{cm}^{3}$ ) was kindly supplied by Petrobras (Brazil) and used as received. Distilled water was used to obtain the microemulsion systems. 


\section{Microemulsion Systems}

Figure 1 shows a schematic ternary phase diagram to determine the microemulsion region. First, the point of maximum solubility of the surfactant in the aqueous phase (P) was obtained. Then, to determine the lateral boundary of the microemulsion region, points on the Surfactant $(\mathrm{S}) / \mathrm{Oil}(\mathrm{O})$ binary $(\mathrm{A}, \mathrm{B}, \mathrm{C}$, and $\mathrm{D})$ were prepared and titrated with water $(\mathrm{W})$ until the cloudy emulsion became clear. The inferior limit was determined by preparing points on the Water $(\mathrm{W}) / \mathrm{Oil}(\mathrm{O})$ binary $(\mathrm{E}, \mathrm{F}, \mathrm{G}$ and $\mathrm{H})$ and titrating with a previously prepared microemulsion (M) until the system changed from a cloudy to a clear aspect. The amounts of water $(\mathrm{W})$, oil $(\mathrm{O})$ and surfactant $(\mathrm{S})$ at each point were obtained by material balances. Points inside the microemulsion region with increasing water content were tested in the diesel engine (Table 1).

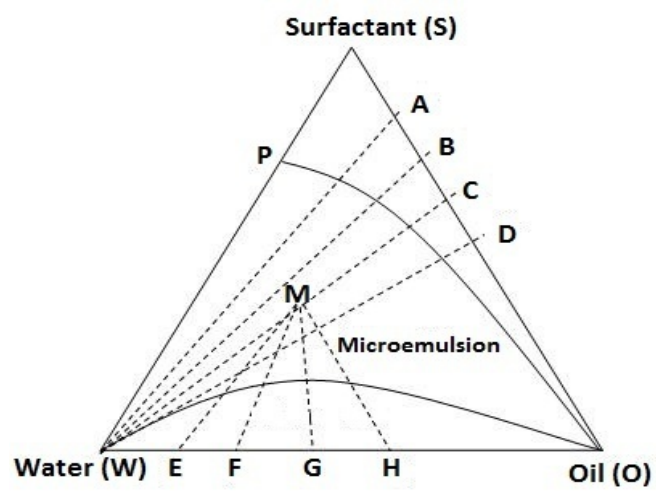

Figure 1: Schematic ternary phase diagram to determine the microemulsion region.

Table 1: Composition of systems used as fuel in the diesel engine.

\begin{tabular}{|c|c|c|c|}
\hline \multirow{2}{*}{ Systems } & \multicolumn{3}{|c|}{ Composition (wt.\%) } \\
\cline { 2 - 4 } & Neat diesel & NFE 5 & Distilled water \\
\hline 1 & 85 & 15 & 0 \\
2 & 83 & 15 & 2 \\
3 & 81 & 15 & 4 \\
4 & 79 & 15 & 6 \\
5 & 77 & 15 & 8 \\
6 & 75 & 15 & 10 \\
7 & 73 & 15 & 12 \\
8 & 71 & 15 & 14 \\
Neat diesel & 100 & 0 & 0 \\
\hline
\end{tabular}

\section{Fuel Characterization}

Kinematic viscosity measurements were accomplished in a HAAKE MARS (RS150) rheometer at $40^{\circ} \mathrm{C}$, with a $150 \mathrm{rpm}$ shear rate during
200 seconds. The relative density $\left(20^{\circ} \mathrm{C}\right)$ was directly measured by using an Anton Paar density meter (DMA $4500 \mathrm{M}$ ). The flash point was obtained by using a Pensky-Martens closed cup apparatus (Petroteste, model: PM-4) with $1.0^{\circ} \mathrm{C} / \mathrm{min}$ heating rate. The cloud point was determined by using a Mettler Toledo automatic titrator (DL 50 model) with a photoelectric sensor, applying a $0.05^{\circ} \mathrm{C} / \mathrm{min}$ cooling rate. The equipment has a sensor that transforms the energy $(\mathrm{mV})$ transmitted through the experimental solution in a photoelectric signal that presents modifications according to changes occurring in the bulk solution during sample cooling or heating. A thermostatic batch $(270 \mathrm{rpm}$ agitation speed) was connected to the phototrode. This methodology was also applied to determine the thermal stability of the systems, considering the maximum and minimum temperature for phase separation. Corrosiveness measurements were performed at $50^{\circ} \mathrm{C}$ in a Koehler apparatus (K25319 Model), using copper strips (12.5 × $75.0 \times 1.5 \mathrm{~mm})$ as working electrode, with surfaces polished with 240 grit silicon carbide paper and then immersed during 3 hours in a sealed stainless steel container with $150 \mathrm{~mL}$ of the fluid to be tested. After this time, the strips were removed from the fluid, washed with hexane, and immediately rated by comparison with lithographed standard strips according to ASTM D130 (2004). In this ASTM standard there are four levels of increasing sulfur-related corrosion, with one corresponding to a slightly tarnished strip, two corresponding to a moderatly tarnished strip, three corresponding to a dark tarnished strip and four corresponding to a corroded strip. Within these numerical ratings, alphabetic sub-ratings are used to describe differences in colors and patterns.

\section{Engine Description}

A single cylinder 4-stroke air-cooled diesel engine (BD $\mathrm{H}$ 5.0) was used during these experiments. The engine specifications are given in Table 2.

Table 2: Specifications of the diesel engine used during the experimental procedure.

\begin{tabular}{|l|l|}
\hline \multicolumn{2}{|c|}{ Diesel Engine } \\
\hline Model & BD H 5.0 \\
Type & single-cylinder, air-cooled, \\
Combustion system & horizontal, 4-stroke \\
Engine speed & direct injection \\
Maximum output & $3000 / 3600 \mathrm{rpm}$ \\
\hline
\end{tabular}




\section{Combustion Studies}

An electric dynamometer was used for loading the engine during the experiments for fuel consumption evaluation. The power was set at $0.00,0.25,0.50,0.75,1.00,1.25$, and $1.50 \mathrm{~kW}$. As the loading supplied by the dynamometer corresponded to $75 \%$ of engine power, values were divided by $0.75(0.00,0.33,0.66,1.00,1.66$, and $2.00 \mathrm{~kW})$. The schematic illustration of the experimental setup is shown in Figure 2.

The fuel feeding system was composed of five inputs, enabling the performance of the test with five samples under the same experimental conditions. The flow rate was measured on a volumetric basis.

Initially the experiments were carried out using neat diesel (15 minutes) to provide the baseline data. Then, engine speed was adjusted to $3500 \mathrm{rpm}$ without loading in the dynamometer, using a tachometer and engine acceleration system for this purpose. With the speed adjusted, the time to burn $15 \mathrm{~mL}$ of neat diesel was measured. Next, the feeding of diesel was closed and the supply of fuel to be tested was initiated. After the engine had worked for 1 minute with this fuel, the time to burn $15 \mathrm{~mL}$ was measured. This process was repeated for all fuels. It is important to point out that the engine was stabilized before taking all measurements.

After fuel consumption measurements without loading in the dynamometer, the engine power was increased using an electric induction key $(0.25,0.50$, $0.75,1.00,1.25$, and $1.50 \mathrm{~kW}$ ) and the same experimental procedure was repeated. The specific fuel consumption was obtained by using Eq. (1).

$$
\mathrm{Q}_{\text {esp }}=\frac{\mathrm{Q}_{\mathrm{o}}}{\mathrm{P}}
$$

where: $Q_{e s p}$ is the specific fuel consumption $(\mathrm{g} / \mathrm{kW} . \mathrm{h}), \mathrm{Q}_{\mathrm{o}}$ is the hourly fuel consumption $(\mathrm{g} / \mathrm{h})$ and $\mathrm{P}$ is the power $(\mathrm{kW})$.

The hourly fuel consumption is then given by:

$\mathrm{Q}_{\mathrm{o}}=\frac{60 \times \mathrm{v} \times \rho}{\mathrm{t}}$

where: $v$ is the volume of fuel burned $(\mathrm{mL})$ in a given time $\mathrm{t}(\mathrm{min})$ and $\rho$ is the fuel density $(\mathrm{g} / \mathrm{mL})$.

\section{Exhaust Gas Analysis}

A GreenLine 8000 (Eurotron) analyzer was used for measuring carbon monoxide (CO), total unburned hydrocarbons (HC) and nitrogen oxides (NOx), all concentrations in ppm. The exhaust gas was collected for each engine load and for all tested fuels. The smoke level in the exhaust gas was measured using a smoke pump (Smoke Tester 7828 - Eurotron), according to ASTM 2156 (2009). This method consists of taking a gas sample from the center of the gas pipe behind the heat exchanger and passing it through a special filter paper. The color of the spot on the filter is compared with a graduated reference scale (a grey scale sheet with 10 different areas numbered from 0 to 9) and is called the "smoke index". The number 0 corresponds to $85 \% \pm 2.5 \%$ reflection. Each numbered area reflects $10 \%$ less than the previous one (Eurotron, 2010).

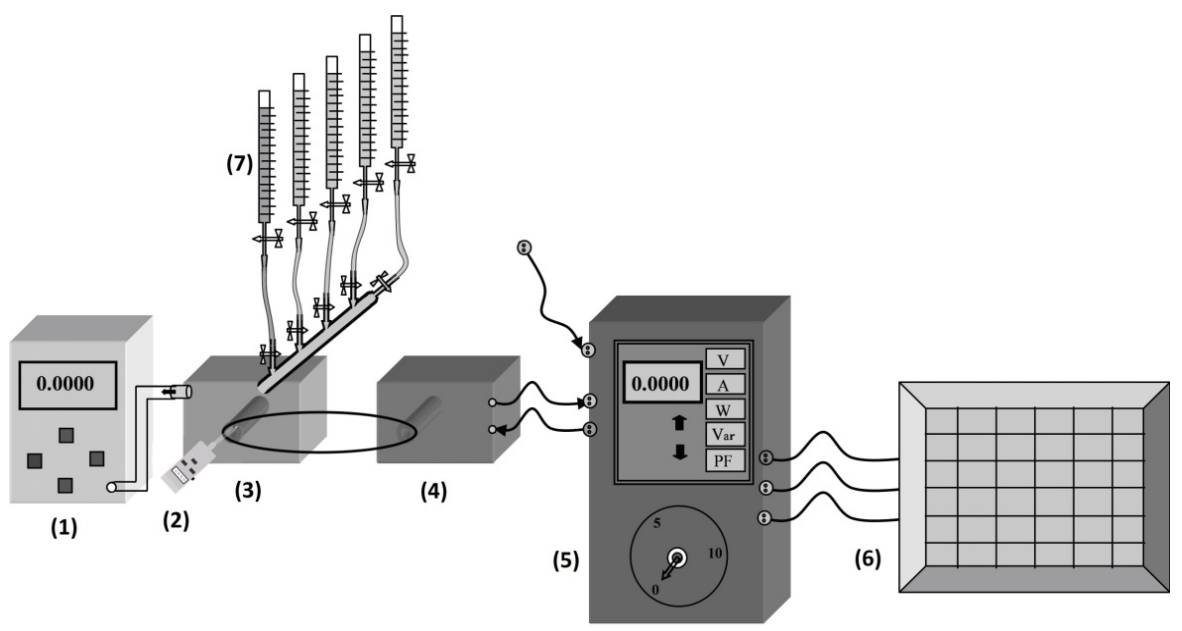

(1) Emission analyzing equipment

(2) Tachometer

(3) Diesel engine

(4) Electric dynamometer

(5) Power adjuster

(6) Energy dissipation system

(7) Fuel feeding system

Figure 2: Experimental Setup with main parts. 


\section{RESULTS AND DISCUSSION}

\section{Ternary Phase Diagram}

Figure 3 shows the ternary phase diagram for the water/NFE5/diesel system. The eight systems evaluated as fuel in the diesel engine were prepared according to Table 1 and are also shown in Figure 3. System 1 is on the surfactant/diesel line, systems 2 to 7 are inside the microemulsion region and system 8 is on the microemulsion/emulsion boundary line.

As shown in Figure 3 and Table 1, points 1 to 8 have increasing water content, with this increase leading to phase separation. According to Bemert et al. (2009), an important criterion for a microemulsion to be used as fuel is that the one phase region extends over a wide temperature range. Figure 4 shows the thermal stability of the studied systems.

System 1, a mixture of diesel and surfactant, is not presented because it only shows phase separation during cooling $\left(17^{\circ} \mathrm{C}\right)$. No phase separation was observed when this system was heated, showing that phase separation during heating for systems 2 to 8 occurred due to the presence of water. By analyzing Figure 4, it can be observed that system 2 (2 wt.\% water) has the highest thermal stability and system 8 (14 wt.\% water) the lowest one.

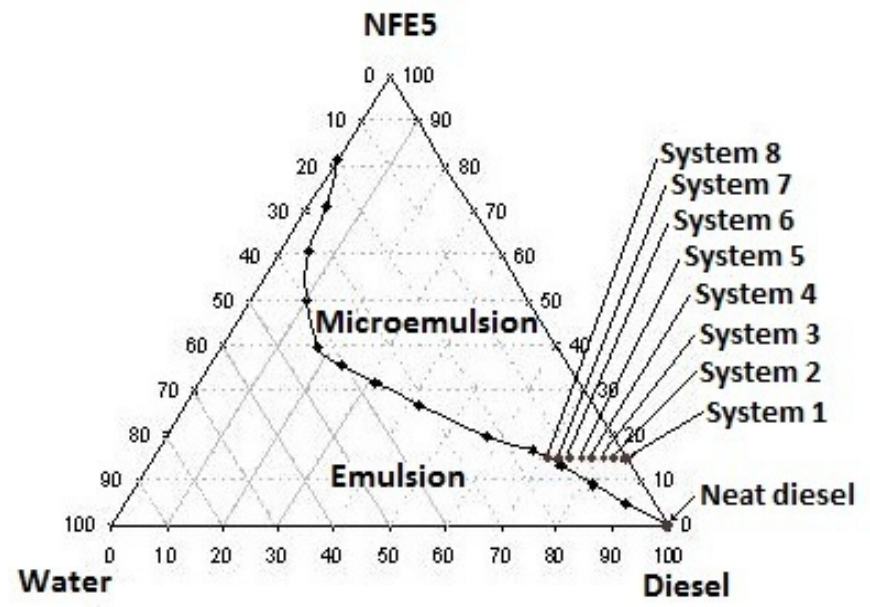

Figure 3: Ternary phase diagram for the water/ NFE5/Diesel system at $28^{\circ} \mathrm{C}$.

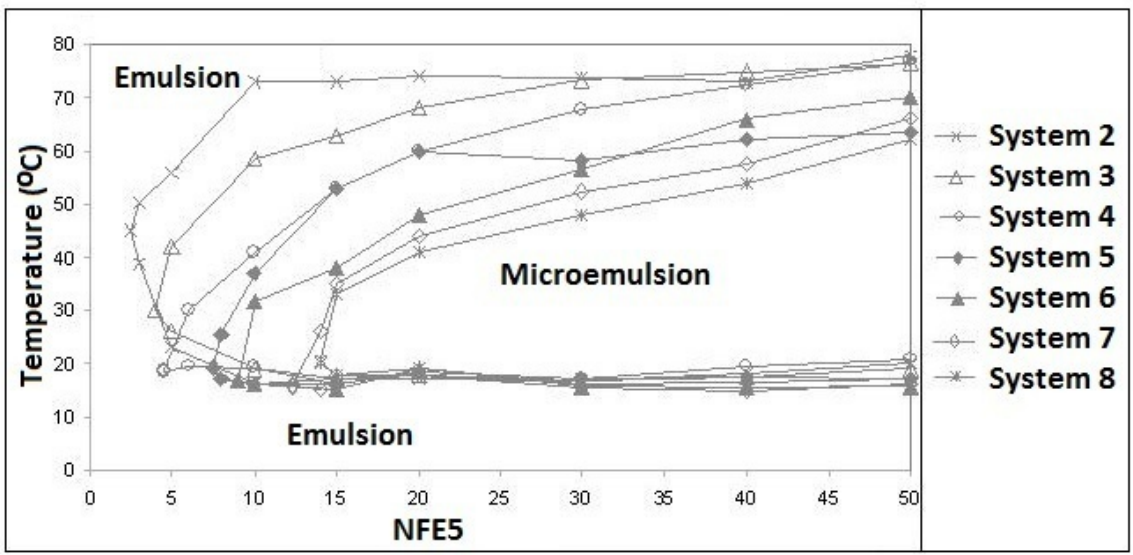

Figure 4: Plots of temperature $\left({ }^{\circ} \mathrm{C}\right)$ versus surfactant mass fraction (wt.\%) to evaluate the thermal stability of the water/NFE5/diesel microemulsion systems. 


\section{Fuel Characterization}

Table 3 shows the properties of the studied fuels and the admissible values according to Brazilian diesel/biodiesel fuel regulations and specifications (ANP, 2006). From Table 3 it can be observed that the increase in the flash point is mainly due to the presence of water, with surfactant showing little influence, all values being in accord with the limit established by ANP.

All fuels had density values higher than those of neat diesel and this value increased with water content. Systems 1 to 7 are in accordance with ANP standards and system 8 is not suitable for use as fuel.

For viscosity, systems 4 to 8 showed values higher than those established by the ANP. The presence of surfactant improves interactions between the oil and water phases. As the water percentile increases, more complex micellar structures are formed, thus resulting in increased viscosity. Values above $5 \mathrm{cSt}$ can damage the fuel injection system, causing incomplete combustion and, consequently, more pollution by carbon monoxide and higher fuel consumption.

The cloud point is an important property of fuels since, at this point, some engines fail to run (Nguyen et al., 2010). The results showed that the presence of surfactant and water did not significantly affect this parameter. The cloud point can be related to the presence of high molecular weight components in diesel, which crystallize with cooling.

For all systems studied, corrosiveness is in accord with Brazilian specifications. Although the expected behavior was an enhancement in the corrosion process due to the water present, this was not observed because in microemulsion systems water is dispersed as small droplets inside the oil-continuous phase and surfactants can serve as corrosion inhibitors.

\section{Specific Fuel Consumption}

To evaluate the specific fuel consumption, neat diesel, diesel/surfactant blend and all microemulsion systems were used (Table 1). As described in the experimental section, the engine speed was adjusted to $3500 \mathrm{rpm}$ and the engine's power to $0.00,0.33$, $0.66,1.00,1.66$, and 2:00 $\mathrm{kW}$. The results are shown in Figure 5.

Table 3: Properties of the evaluated fuels.

\begin{tabular}{|c|c|c|c|c|c|}
\hline System & $\begin{array}{c}\text { Flash point } \\
\left({ }^{\circ} \mathrm{C}\right)\end{array}$ & $\begin{array}{c}\text { Density } \\
\left(20^{\circ} \mathrm{C}-\mathrm{Kg} / \mathrm{m}^{3}\right)\end{array}$ & $\begin{array}{c}\text { Viscosity } \\
\left(40^{\circ} \mathrm{C}-\mathrm{cSt}\right)\end{array}$ & $\begin{array}{c}\text { Cloud point } \\
\left({ }^{\circ} \mathrm{C}\right)\end{array}$ & Corrosivity \\
\hline ANP & $\min .38 .0$ & 820 to 865 & $\max .2$ to 5 & - & $\max .1$ \\
\hline 1 & 40.7 & 842.5 & 4.2 & 17 & 1a \\
\hline 2 & 40.5 & 845.1 & 4.4 & 17 & $1 \mathrm{a}$ \\
\hline 3 & 41.2 & 846.0 & 5.0 & 17 & 1a \\
\hline 4 & 41.8 & 848.7 & 5.7 & 16 & 1a \\
\hline 5 & 43.7 & 858.2 & 7.0 & 16 & 1a \\
\hline 6 & 44.5 & 860.8 & 7.1 & 16 & 1a \\
\hline 7 & 43.4 & 864.5 & 7.2 & 18 & 1a \\
\hline 8 & 45.1 & 867.6 & 7.2 & 18 & 1a \\
\hline Neat diesel & 40.3 & 820.5 & 2.2 & 17 & $1 \mathrm{a}$ \\
\hline
\end{tabular}

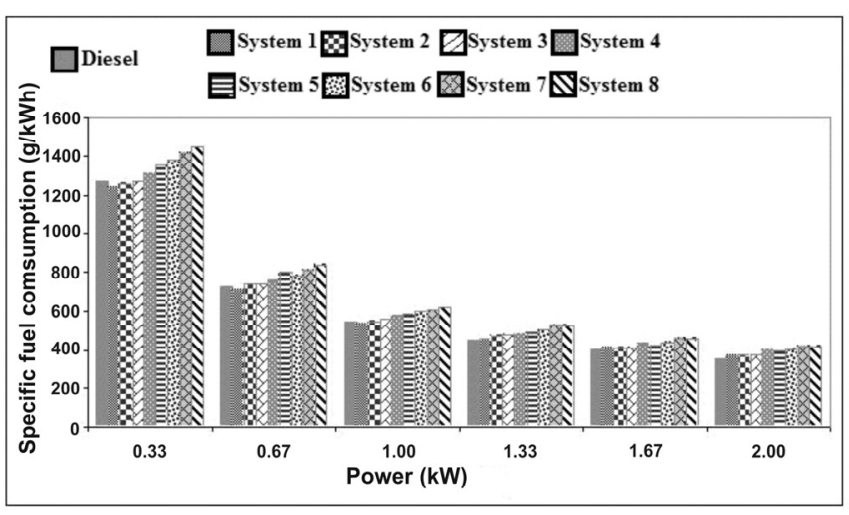

(a)

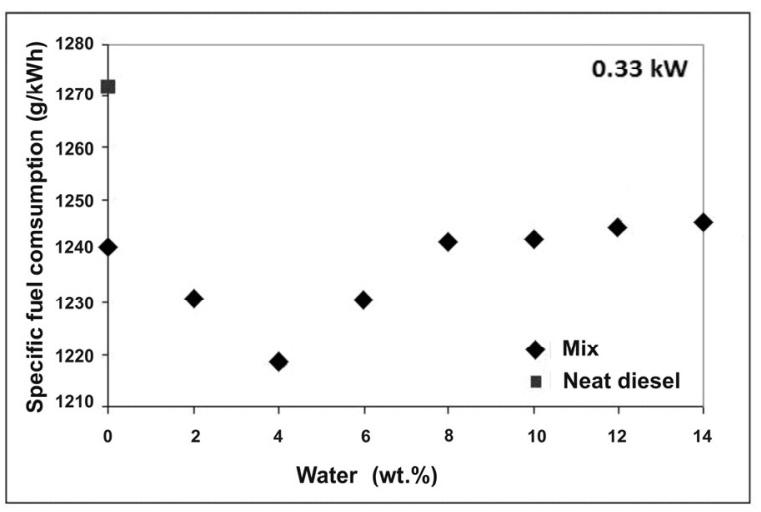

(b)

Figure 5: Plots of break specific fuel consumption: (a) as a function of engine power and (b) versus water percentage, at $0.33 \mathrm{~kW}$. 
By analyzing Figure 5(a), one can observe that the fuel burning efficiency increased with engine power. The presence of water in the microemulsion systems decreased the superior calorific power (SCP) because water is not a fuel and less diesel is actually contained in each volume of burned fuel. Table 4 shows the SCP results of some studied systems.

Table 4: Superior calorific power (SCP) of some studied systems.

\begin{tabular}{|c|c|c|c|}
\hline \multicolumn{3}{|c|}{ Composition (wt.\%) } & \multirow{2}{*}{$\begin{array}{c}\text { SCP } \\
\text { (kcal/kg) }\end{array}$} \\
\cline { 1 - 3 } Water & NFE 5 & Diesel & 10705.36 \\
0 & 0 & 100 & 7901.78 \\
0 & 100 & 0 & 10139.74 \\
0 & 15 & 85 & 9946.12 \\
4 & 15 & 81 & \\
\hline
\end{tabular}

According to Lin and Chen (2006), the calorific value of neat diesel fuel is higher than that of diesel emulsions, which increases the fuel consumption rate for the same output power. The absorption of partial heat released from combustion by the latent heat of water in the emulsion may also cause a decrease in engine power output; thus, the emulsion requires higher break specific fuel consumption.

Figure 5 (b) shows the plot of break specific fuel consumption versus water percentage present in the microemulsion fuels at $0.33 \mathrm{~kW}$. The zero point corresponds to the diesel/surfactant blend. The break specific fuel consumption $\left(\mathrm{Q}_{\text {esp }}\right)$ was calculated considering only diesel and surfactant volumes, according to Eq. (3):

$\mathrm{Q}_{\mathrm{esp}}=\frac{60 \times \mathrm{v} \times \mathrm{F} \times \rho}{\mathrm{P} \times \mathrm{t}}$

where: $\mathrm{v}$ is the volume of fuel used in each system $(\mathrm{mL})$ in a given time $\mathrm{t}(\mathrm{min}), \mathrm{F}$ is the factor to remove water from the system (Table 5), $\rho$ is the fuel density $(\mathrm{g} / \mathrm{mL})$ and $\mathrm{P}$ is the power $(\mathrm{kW})$.

Table 5: Values of $F$ considering only diesel and surfactant in each system.

\begin{tabular}{|c|c|}
\hline System & F \\
\hline 1 & 1.00 \\
2 & 0.98 \\
3 & 0.96 \\
4 & 0.94 \\
5 & 0.92 \\
6 & 0.90 \\
7 & 0.88 \\
8 & 0.86 \\
Neat diesel & 1.00 \\
\hline
\end{tabular}

In Figure 5(b) it can be observed that the presence of water in the microemulsion systems improves diesel fuel burning. It can also be observed that, for the water/NFE5/diesel microemulsion systems, there is an optimal water content (4 wt.\%) that improves the combustion reaction, but even with 14 wt.\% water content the results were better than those obtained for neat diesel.

According to Lif and Holmberg (2006), when a water-in-diesel emulsion is heated, the water is first vaporized because it is more volatile than diesel. The vaporization will cause microexplosions in the continuous hydrocarbon phase that help in the atomization of the fuel. The violent disintegration is beneficial for the mixing of fuel and air because the fuel-air interfacial layer will be larger than the corresponding process without microexplosions, improving the combustion reaction and burning efficiency, thus reducing fuel consumption.

\section{Exhaust Gas Emissions}

Table 6 shows the emissions of carbon monoxide (CO), total unburned hydrocarbons (HC), nitrogen oxides (NOx) and smoke for all studied systems.

Carbon monoxide emissions for the surfactant/diesel blend (system 1) and all microemulsion fuels (systems 2-8) were higher than those obtained for neat diesel, but this difference decreased with increasing engine power. When the engine works at low power, temperatures inside the combustion chamber are lower and burning efficiency decreases. Because microemulsions fuels contain water in their composition, which absorbs heat for vaporization, with increasing water content the emission of carbon monoxide increased due to a reduction in temperature in the combustion chamber, which causes a decrease in combustion efficiency, as also observed by Lif et al. (2010).

The emissions of total unburned hydrocarbons (HC) presented no definite trend, increasing or decreasing, with engine power and water content in the microemulsion. According to Lif and Holmberg (2006), the presence of water and, especially, the presence of an oil-water interface is one reason for improved combustion efficiency. Improving combustion and burning efficiencies should reduce the amount of unburned hydrocarbons, which was not observed in all conditions studied.

The formation of nitrogen monoxide (NO) occurs via the reaction of gaseous nitrogen $\left(\mathrm{N}_{2}\right)$ and molecular oxygen $\left(\mathrm{O}_{2}\right)$ present in the atmosphere. However, this reaction does not occur easily due to the amount of energy required (Carvalho Júnior e Lacava, 2003; Gallego et al., 2000). When a fuel is burned in a diesel engine, the temperature in the combustion chamber is very high, providing the required energy for NO formation, which is an undesired gas for the environment. The NO formed in combustion can easily combine with oxygen to form $\mathrm{NO}_{2}$. The sum of $\mathrm{NO}$ and $\mathrm{NO}_{2}$ is commonly referred to as NOx. 
Table 6: Results of gaseous emissions for all studied systems: carbon monoxide (CO), total unburned hydrocarbons (HC), nitrogen oxides (NOx) and smoke.

\begin{tabular}{|c|c|c|c|c|c|c|c|c|c|}
\hline \multirow{2}{*}{$\begin{array}{c}\text { Power } \\
(k W)\end{array}$} & \multicolumn{9}{|c|}{ System (S) } \\
\hline & Diesel & S 1 & S 2 & S 3 & S 4 & S 5 & S 6 & S 7 & S 8 \\
\hline \multicolumn{10}{|c|}{ Carbon Monoxide (CO - ppm) } \\
\hline 0.33 & 470 & 492 & 522 & 557 & 613 & 647 & 681 & 805 & 934 \\
\hline 0.67 & 440 & 382 & 435 & 447 & 488 & 550 & 596 & 606 & 692 \\
\hline 1.00 & 430 & 369 & 385 & 429 & 436 & 446 & 466 & 524 & 580 \\
\hline 1.33 & 432 & 379 & 406 & 434 & 441 & 422 & 442 & 458 & 488 \\
\hline 1.67 & 379 & 391 & 437 & 433 & 481 & 439 & 441 & 490 & 500 \\
\hline 2.00 & 430 & 511 & 510 & 487 & 540 & 415 & 418 & 425 & 463 \\
\hline \multicolumn{10}{|c|}{ Nitrogen Oxides (NOx - ppm) } \\
\hline 0.33 & 75 & 90 & 83 & 82 & 78 & 70 & 71 & 63 & 52 \\
\hline 0.67 & 74 & 117 & 107 & 103 & 103 & 80 & 81 & 75 & 66 \\
\hline 1.00 & 94 & 138 & 125 & 117 & 119 & 109 & 98 & 100 & 94 \\
\hline 1.33 & 122 & 161 & 162 & 147 & 146 & 129 & 121 & 114 & 114 \\
\hline 1.67 & 146 & 197 & 178 & 155 & 166 & 145 & 137 & 130 & 121 \\
\hline 2.00 & 210 & 221 & 188 & 162 & 177 & 139 & 130 & 113 & 105 \\
\hline \multicolumn{10}{|c|}{ Total Unburned Hydrocarbons (HC - ppm) } \\
\hline 0.33 & 594 & 658 & 647 & 757 & 683 & 506 & 457 & 404 & 390 \\
\hline 0.67 & 668 & 670 & 933 & 811 & 788 & 492 & 416 & 485 & 396 \\
\hline 1.00 & 388 & 391 & 599 & 577 & 555 & 684 & 687 & 610 & 546 \\
\hline 1.33 & 749 & 830 & 917 & 820 & 859 & 518 & 523 & 555 & 484 \\
\hline 1.67 & 180 & 366 & 479 & 480 & 460 & 128 & 59 & ND* & ND \\
\hline 2.00 & 406 & 423 & 821 & 355 & 441 & 193 & 271 & 155 & 170 \\
\hline \multicolumn{10}{|c|}{ Smoke } \\
\hline 0.33 & 1 & 0 & 0 & 0 & 0 & 0 & 0 & 0 & 0 \\
\hline 0.67 & 1 & 1 & 1 & 1 & 1 & 0 & 0 & 0 & 0 \\
\hline 1.00 & 2 & 1 & 1 & 1 & 1 & 1 & 1 & 1 & 1 \\
\hline 1.33 & 3 & 1 & 1 & 1 & 1 & 1 & 1 & 1 & 1 \\
\hline 1.67 & 4 & 2 & 2 & 2 & 2 & 2 & 2 & 2 & 2 \\
\hline 2.00 & 5 & 3 & 3 & 3 & 3 & 3 & 3 & 3 & 3 \\
\hline
\end{tabular}

* ND - not detected - with high percentage of water in the exhaust, part of HC can remain in the condensed water, and not be read by the instrument used.

When the engine power is relatively high, a peak in pressure occurs inside the combustion chamber. The combination of high pressure and high engine load leads to high temperatures and, consequently, increased NOx emissions. According to Lin and Wang (2004), the formation of nitrogen oxides (NOx) can arise from: nitrogen bearing fuel, excess oxygen, excessive high burning gas, and excessive time in the reaction zone.

As can be observed in Table 6, NOx emissions increased with increasing engine power and decreased with increasing water percentile in the microemulsion fuels. The increase in NOx emissions is attributed to the large amount of surfactant in the systems (15 wt.\%), as can be observed in system 1, which has only surfactant and diesel in its composition.

The smoke level was increased by an increase in engine power. Microemulsion fuels reduced black smoke emissions because the presence of water in microemulsions reduces the combustion temperature, consequently decreasing the production of soot. As mentioned earlier, water improves combustion and therefore reduces the formation of smoke.

According to Ochoterena et al. (2010) the use of emulsions and microemulsions reduced exhaust soot emissions $81 \%$ and $89 \%$, respectively. They attributed this reduction to the combined effects of lower flame temperatures, lower concentrations of soot in the flames, rapid evaporation of water and the presence of hydroxyl radicals from water dissociation, all of which promote the oxidation of soot to CO.

To provide a general explanation for $\mathrm{CO}$, NOx, $\mathrm{HC}$, and smoke emissions, it is necessary to develop a detailed study of engine design and the mechanisms of combustion processes at high temperatures, which may follow three points: the thermal destruction of molecules (Tancell et al., 1995), the direct emissions of unburned fuels (Willians et al., 1989) and pyrosynthesis (Bjorseth, 1983). Combustion of diesel involves atomization, 
evaporation, mixing with air and burning at high temperature and pressure. All processes are complex and the addition of components such as surfactants and water to diesel fuel leads to changes in these processes, with changes in density, viscosity, vapor pressure and other physical and chemical properties, resulting in a system with improved combustion properties in diesel engines.

\section{CONCLUSIONS}

In this study, the preparation, characterization, engine performance and emissions of a surfactant/diesel blend and of microemulsion systems were investigated. The main conclusions can be summarized as follows:

1) Density and viscosity of all studied systems were higher than those obtained for neat diesel and these properties increased with increasing water content. The results for the cloud point and corrosiviness showed that the presence of surfactant and water did not significantly affect these parameters. In general, for microemulsions with water/15 wt.\% NFE5/diesel, only systems with up to $6 \%$ water meet the Brazilian diesel/biodiesel fuel regulations and specifications;

2) According to the results for specific fuel consumption, the presence of water in microemulsions improves diesel fuel combustion;

3) Compared with neat diesel, $\mathrm{CO}$ emissions were increased for the diesel/surfactant blend and all microemulsions fuels, with this difference decreasing with increasing engine power;

4) There is no definite trend for total unburned hydrocarbon emissions (HC) with increasing engine power and water content.

5) NOx emissions increased with increasing engine power and decreased with increasing water content in the microemulsion fuels. The former is mainly due to the high amount of surfactant added to the systems and the latter, to a reduction in the temperature inside the combustion chamber;

6) A reduction in black smoke emissions was observed for the surfactant/diesel blend and all microemulsion fuels, as compared with neat diesel. The presence of water and surfactant improves the combustion reaction and, therefore, reduces the formation of black smoke;

7) In this research, 15 wt.\% surfactant was used in all microemulsion systems. This quantity is high and was chosen in order to evaluate the maximum concentration of water that can be added to the surfactant/diesel mixture to obtain a microemulsion.
New studies must be performed seeking to reduce the amount of surfactant in the systems, which would make it more feasible for practical purposes.

\section{NOMENCLATURE}

$\begin{array}{ll}\text { ANP } & \begin{array}{l}\text { Brazilian National Agency } \\ \text { of Petroleum, Natural Gas } \\ \text { and Biofuels } \\ \text { American Society for }\end{array} \\ \text { ASTM } & \begin{array}{l}\text { Testing and Materials } \\ \text { factor to remove water from } \\ \text { systems }\end{array} \\ \text { F } & \begin{array}{l}\text { total unburned hydrocarbons } \\ \text { total acid number }\end{array} \\ \text { HC } & \text { Initial boiling point } \\ \text { IAT } & \text { microemulsion } \\ \text { IBP } & \text { ethoxylated nonylphenol 5 }\end{array}$

EO

NOx nitrogen oxides

$\mathrm{O} \quad$ oil phase

$\mathrm{o} / \mathrm{w} \quad$ oil-in-water emulsion or microemulsion

o/w/o oil-in-water-in-oil - threephase emulsions

$\mathrm{P} \quad$ power

$\mathrm{kW}$

$\mathrm{P} \quad$ point of maximum solubility of the surfactant

Q $\quad$ specific fuel consumption $\mathrm{g} / \mathrm{kW} . \mathrm{h}$

$\mathrm{Q}_{0} \quad$ hourly fuel consumption $\mathrm{g} / \mathrm{h}$

S surfactant

SCP superior calorific power

$\mathrm{t}$ time

$\min$

W aqueous phase

w/o water-in-oil emulsion or microemulsion

$\rho \quad$ fuel density $\mathrm{g} / \mathrm{mL}$

$\mathrm{v} \quad$ volume of fuel burned $\mathrm{mL}$

\section{ACKNOWLEDGMENTS}

The authors would like to thank the ANP (Agência Nacional do Petróleo Gás Natural e Biocombustíveis Brazilian National Agency of Petroleum, Natural Gas and Biofuels) for financial support.

\section{REFERENCES}

Abu-Zaid, M., Performance of single cylinder, direct injection diesel engine using water fuel emulsions. Energy Conversion and Management, 
45, p. 697-705 (2004). DOI:10.1016/S01968904(03)00179-1

Alahmer, A., Yamin, J., Sakhrieh, A., Hamdan, M. A., Engine performance using emulsified diesel fuel. Energy Conversion and Management, 51, p. 17081713 (2010). DOI:10.1016/j.enconman.2009.11.044 ANP - Resolution Number 15/2006 - Normas para comercialização de óleo diesel e misturas de óleo diesel/biodiesel-B2 automotivo (Standards for commercialization of diesel oil and diesel/ biodiesel B2 automotive blends). Brazilian National Agency of Petroleum, Natural Gas and Biofuels (ANP), July 17, 2006. Available at $<$ http://nxt.anp.gov.br/NXT/gateway.dll?f=templates $\&$ fn=default.htm\&vid=anp:10.1048/enu $>$ (Accessed in May 2010). (In Portuguese).

Armas, O., Ballesteros, R., Martos, F. J., Agudelo, J. R., Characterization of light duty diesel engine pollutant emissions using water-emulsified fuel. Fuel, 84, p. 1011-1018 (2005). DOI:10.1016/j.fuel.2004.11.015

ASTM 2156, Standard Test Method for Smoke Density in Flue Gases from Burning Distillate Fuels. American Society for Testing and Materials (ASTM) (2009). DOI: 10.1520/D2156-09

ASTM D130, Standard Test Method for Corrosiveness to Copper from Petroleum Products by Copper Strip Test. American Society for Testing and Materials (ASTM) (2004). DOI: 10.1520/D0130-04E01

Bemert, L., Engelskirchen, S., Simon, C., Strey, R., Low emissions with microemulsion-fuels. Prepr. Pap.-Am. Chem. Soc., Div. Fuel Chem., 54, 290 (2009).

Bjorseth, A., Handbook of polycyclic aromatic hydrocarbons. New York: Marcel Dekker Inc. (1983).

Carvalho Júnior, J. A., Laçava, P. T., Emissões em processos de combustão (Emissions from combustion processes). São Paulo: Editora UNESP (2003). (In Portuguese).

Castro Dantas, T. N., Dantas Neto, A. A., Silva A. C., New microemulsion systems using diesel and vegetable oils. Fuel, 80, p. 75-81 (2001). PII: S0016-2361(00)00068-5.

Crookes, R. J., Kiannejad, F., Nazha, M. A. A., Systematic assessment of combustion characteristics of biofuels and emulsions with water for use as diesel engine fuels. Energy Convers. Mgmt., 38, (15-17), p. 1785-1795 (1997). PII: S0196-8904(96)00202-6.

Eurotron, Instruction Manual MM850371. $4^{\text {th }}$ Edition. In PDF. Available at: <http://www.om.gr/MM850482-04_UniGas1000.pdf> (Accessed in May 2010).
Fernandes, M. R., Dantas Neto, A. A., Barros Neto, E. L., Castro Dantas, T. N., Moura, M. C. P. A., Combustível microemulsionado base-diesel (Dieselbased microemulsion fuel). Brazilian Patent Deposit Number PI 0600616-7 A (2006). (In Portuguese).

Gallego, A. G., Martins, G., Gallo, W. L. R., Emissões de NOx em turbinas a gás: mecanismos de formação e algumas tecnologias de redução (Gas turbines NOx emissions: formation mechanisms and some reduction technologies). Revista de Ciência \& Tecnologia, 15, p. 13-22 (2000). (In Portuguese).

Hoar, T. P., Schulman, J. H., Transparent water-inoil dispersions oleophatics hydromicelle. Nature, London: 152, (102) (1943).

Lif, A., Holmberg, K., Water-in-diesel emulsions and related systems. Advances in Colloid and Interface Science, 123-126, p. 231-239 (2006). DOI: 10.1016/j.cis.2006.05.004

Lif, A., Stark, M., Nydén, M., Holmberg, K., Fuel emulsions and microemulsions based on FischerTropsch diesel. Colloids and Surfaces A: Physicochemical and Engineering Aspects, 354, p. 91-98 (2010). DOI: 10.1016/j.colsurfa.2009.08.020

Lin, C-Y, Chen, L-W., Engine performance and emission characteristics of three-phase diesel emulsions prepared by an ultrasonic emulsification method. Fuel, 85, p. 593-600 (2006). DOI: 10.1016/j.fuel.2005.09.007

Lin, C.-Y., Wang, K.-H., Diesel engine performance and emission characteristics using three-phase emulsions as fuel. Fuel, 83, p. 537-545 (2004). DOI: 10.1016/j.fuel.2003.08.012

Nabi, M. N., Akhter, M. S., Zaglul Shahadat, M. M., Improvement of engine emissions with conventional diesel fuel and diesel-biodiesel blends. Bioresource Technology, 97, p. 372-8 (2006).

Nguyen, T., Do, L., Sabatini, D. A., Biodiesel production via peanut oil extraction using dieselbased reverse-micellar microemulsions. Fuel, 89, p. 1-7 (2010). DOI: 10.1016/j.fuel.2010.03.021

Ochoterena, R., Lif, A., Nydén, M., Sven, A., Denbratt, I., Optical studies of spray development and combustion of water-in-diesel emulsion and microemulsion fuels. Fuel, 89, p. 122-132 (2010). DOI: 10.1016/j.fuel.200906.039

Papagiannakis, R. G., Rakopoulos, C. D., Hountalas, D. T., Rakopoulos, D. C., Emission characteristics of high speed, dual fuel, compression ignition engine operating in a wide range of natural gas/diesel fuel proportions. Fuel, 89, p. 13971406 (2010). DOI: 10.1016/j.fuel.2009.11.001

Park, K., Kwak, I., The Effect of water emulsified fuel on a motorway-bus diesel engine. KSME 
International Journal, 18 (11), 2049-2057 (2004).

Peckham, J., Citgo microemulsion cuts NOx 25$27 \%$, PM by $40-52 \%$ in test. Diesel Fuel News, Oct 15 (2001).

Rakopoulos, C. D., Antonopoulos, K. A., Rakopoulos, D. C., Hountalas, D. T., Giakoumis, E. G., Comparative performance and emissions study of a direct injection Diesel engine using blends of Diesel fuel with vegetable oils or bio-diesels of various origins. Energy Conversion and Management, 47, p. 3272-3287 (2006). DOI: 10.1016/j.enconman.2006.01.006

Sarvi, A., Kilpinen, P., Zevenhoven, R., Emissions from large-scale medium-speed diesel engines: 3 . Influence of direct water injection and common rail. Fuel Processing Technology, 90, p. 222-231 (2009). DOI:10.1016/j.fuproc.2008.09.003

Selim, M. Y. E., Elfeky, S. M. S., Effects of diesel/water emulsion on heat flow and thermal loading in a precombustion chamber diesel engine. Applied Thermal Engineering, 21, p. 1565-1582 (2001).

Singh, P. J., Khurma, J., Singh, A., Preparation, characterization, engine performance and emission characteristics of coconut oil based hybrid fuels. Renewable Energy, 35, p. 20652070 (2010). DOI: 10.1016/j.renene.2010.02.007

Tancell, P. J., Rhead, M. M., Pemberton, R. D., Braven, J., Survival of polycyclic aromatic hydrocarbons during diesel combustion. Environmental Science and Technology, 29, p. 2871-2876 (1995). DOI: 10.1021/es00011a025

Wang, L.-P., Fu, W.-B., An analysis of the combustion characters and the mechanism of oil-consumption economy for diesel engines using water-blended oil. Fuel Processing Technology, 72, p. 47-61 (2001). PII: S0378-3820(01).00183-7.

Williams, P. T., Abbass, M. K., Andrews, G. E., Bartle, K. D., Diesel particulate emissions: the role of unburned fuel. Combustion Flame, 75, p. 1-24 (1989). 